Egyptian Journal of Rabbit Science, 28 (2): 333-350 (2018)

\title{
SEXUAL RECEPTIVITY, REPRODUCTIVE HORMONES AND PERFORMANCE TRAITS OF AGING FEMALE RABBITS AS AFFECTED BY DIFFERENT SOURCES OF UNSATURATED FATTY ACIDS
}

\author{
M.A. El-Sawy ${ }^{1}$, A.E. Elkamhawy ${ }^{1}$, M.M. Abdellah ${ }^{1}$, T.A. Sadaka ${ }^{1}$ and \\ M.I. Shourrap ${ }^{2}$ \\ 1- Anim. Prod. Res. Instit., Agric. Res. Cent., Egypt \\ 2- Poult. Prod. Dep., Fac. of Agric., Ain Shams Uni., Cairo, Egypt. \\ E-mail: mohamedelspeiy@yahoo.com
}

Sixty V-lines doe rabbits, 24 months of age weighing $3244 \pm 58.9 \mathrm{~g}$, which had low conception rate and repeated refuse of mating were used. Rabbits were randomly divided into five equal treatment groups and orally administered with $3 \mathrm{ml}$ of different sources of oil/doe/day, for eleven consecutive days prior to insemination as follows: group 1 sterilized water and served as control (C), group 2 sesame oil (Ses), group 3 linseed oil (Lin), group 4 sunflower oil (Sun), group 5 mixture oil (Mix) containing equal portions of Ses, Lin and Sun oils. Estradiol (E217- $\beta$ ), progesterone $(P 4)$ and prostaglandin $\left(P G F_{2 \alpha}\right)$, sexual receptivity of does, fertility rate, litter size and bunny weight at birth were measured. Results revealed that:

1 - All treated groups represented significant $(P \leq 0.01)$ increase of hormonal profile (E217- $\beta, P 4$ and $P G F_{2 \alpha}$ ), sexual receptivity, fertility rate, litter size and bunny weight at birth compared to the control group.

2- Aged doe rabbits supplemented with Ses and Sun oils recorded highest concentrations of $E 2_{17 \beta}$ and $P G F_{2 \alpha}$ and decrease of $P_{4}$ than Lin and Mix oils or the control groups.

3-Sexual receptivity and fertility rate were improved $(P \leq 0.01)$ for groups supplemented with Ses and Sun oils compared with other groups.

4- Litter size and bunny weight at birth were significantly $(P \leq 0.01)$ increased for groups supplemented with Lin and Mix oils compared with other groups.

Conclusively, supplementing the aged doe rabbits with Ses, lin and Sun oils or their mixture for 11 consecutive days perior 
insemination could be beneficial for improving estradiol and prostaglandin hormone with subsequent improvement of does receptivity, litter size and bunny weight combined with progesterone reduction

Key words: Aging doe rabbits, reproductive hormones, fertility rate, sexual receptivity.

Reproductive rabbits capacity is starting at puberty age, increases for a short time and eventually decreases at a rate characteristic of the species (Talbert, 1968). Falling in fertility with age suppose due to an attrition of the oocyte population (Ingram et al., 1958), increase in the incidence of defective oocytes (Henderson and Edwards, 1968) and reduce in the potency of the uterus to maintain pregnancy (Adams, 1970). Furthermore, ovaries can not produce steroid hormones in aging animals (Deng, 2012) and reduce the capacity of the hypothalamic-pituitary-gonadal axis in reproductive system (Walker et al., 2013).

In context, aging women oocytes may contain abnormal chromosome division, decreased mitochondrial quality, including the accumulation of mutations in the mitochondrial DNA and low ATP production, increased oxidative stress, and decreased antioxidant levels, also, decreases drastically the quality of fertility with the qualitative deterioration of oocytes (Meldrum et al., 2016). In addition, old age mares is associated with increased accumulation of inflammatory cells within the endometrium, reduced pregnancy rate, and increased chance of pregnancy loss when compared with younger mares (Carnevale and Ginther, 1992). Also, Simmen et al., (2015) reported that aging of mice uteri leads to the down regulation of several genes associated with cell proliferation, indicating the presence of senescent cells with impaired proliferation owing to uterine aging. On the other hand, aging female rabbits able to still produce an adequate number of fertilizable oocytes which are capable of normal development provided but uterus incapable to maintained pregnancy (Maurer and Foote, 1971) which lead to decreased litter size this is not due to low ovulation rate (Thorneycroft and Soderwall, 1969). Furthermore, decrease in progesterone flow by the ovaries has been implicated failure pregnancy in aging rabbits (Maurer and Foote, 1972). In the context, Larson et al., (1973) who reported that aging female rabbits were given supplemental exogenous progesterone and/or oestradiol benzoate in an effort to increase reproductive efficiency. Also, elevated basal FSH and LH can induce reproductive and endocrinological signs of aging women (Ahmed et al., 1994). 
Several studies on lipids metabolism have shown that alpha linolenic acid (ALA) (18:3 n-3) and linoleic acid (LA) (18:2 n-6) can not be synthesized in the most mammals' species including rabbits due to the lack of appropriate fatty acid desaturase enzymes and consequently they must be supplied in the diet (Vrablik and Watts, 2013).

An important function of PUFAs is the components of phospholipids in cell membrane. Different types of cells, membranes and phospholipids have different compositions of PUFAs and this fatty acid composition may affective by metabolism, state of cell activation, hormone and genetic factors (Calder, 2015). The physical features of cell membrane that include fluidity and permeability are influenced by PUFAs acids composition of cell membrane. Also, the PUFAs as precursors are related to PG family synthesis and steroidogenesis (Stocco et al., 2005).

Polyunsaturated fatty acids (PUFAs) influence oocyte maturation, fertilization and subsequent development through altering the biochemical composition of follicular fluid (Bilby et al., 2006). Another studies by Scott et al., (1995) showed that cows fed with supplements containing long chain PUFAs present stronger estrous had more active ovaries and less derived $\mathrm{PGF}_{2 \alpha}$ was requiring for estrous induction. Another study by Fouladi-Nashta et al., (2009) reported that fatty acid composition in granulosa cells were changed by supplementation and it had influence to oocyte maturation and subsequent development in vivo. Otherwise, Wathes et al., (2007) reported that omega-3 a one of PUFAs regulates different types of reproductive function in mammals.

Cholesterol is described to be the precursor for the synthesis of steroid hormones, $\mathrm{P} 4$ and E2, while AA is the precursor for $\mathrm{PGF}_{2 \alpha}$ (Santos et al., 2008), $\mathrm{PGF}_{2 \alpha}, \mathrm{P} 4$ and $\mathrm{E} 2$ are essential hormones induct in ovulation, oestrous cycle and maintenance of pregnancy in dairy cows (Field and Taylor, 2008).

Therefore, the objective of this study was to investigate the effect of oral administration of polyunsaturated fatty acids (different sources of omega-3 and omega-6) on some reproductive hormones, sexual receptivity prior insemination, fertility and litter size and bunny weight at birth for aged doe rabbits.

\section{MATERIALS AND METHODS}

The present work was carried out at a private rabbit farm at Qaluobia Governorate from October 2017 to April 2018 (temperature ranged from 19 to $27^{\circ} \mathrm{C}$ while, humidity was 43 to $54 \%$ and light period $16 \mathrm{hr}$ light : $8 \mathrm{hr}$ dark). 


\section{Experimental design:}

Sixty aged V-line does 24 month age, with average body weight of $3244 \pm 58.9 \mathrm{~g}$, had low conception rate and repeated refuse of mating were used for the present study.

Rabbits were randomly divided into five equal treatment groups and orally administered with $3 \mathrm{ml}$ of different sources of oil/doe/day, for eleven consecutive days prior insemination as follows:

Group 1: $3 \mathrm{ml}$ sterilized water was given orally and served as control group $(\mathbf{C})$,

Group 2: Orally $3 \mathrm{ml}$ of Sesame oil* (Ses),

Group 3: Orally $3 \mathrm{ml}$ of Linseed oil* (Lin),

Group 4: Orally $3 \mathrm{ml}$ of Sunflower oil* (Sun),

Group5: Orally $3 \mathrm{ml}$ of Mixture oils** (Mix)

*Mixture oils. Contains equal portion of Ses, Lin and Sun oils.

\section{Housing and management:}

The rabbits were housed in a naturally ventilated building and kept in individual wire galvanized cages $(60 \times 55 \times 40 \mathrm{~cm})$. Batteries were accommodated with feeders for pelleted rations and automatic drinkers. Animals were kept under similar management, hygienic conditions, healthy and clinically free of external and internal parasites.

\section{Diet nutrient profiles:}

Does were allowed to a standard pelleted diet (Table 1). Feed and water were available ad libitum.

Polyunsaturated fatty acids composition of Ses, Lin and Sun oils are presented in Table 2.

Does were inseminated using a heterospermic pool diluted 3 times (1 Semen : 3 extender). A pool of semen was collected from bucks of proven fertility for artificial insemination (AI), which performed by depositing $0.5 \mathrm{ml}$ of fresh diluting semen deeply in the upper of vagina by sterile catheter.

Semen was diluted with extender stored at room temperature $\left(20^{\circ}\right.$ C) and used within $4 \mathrm{hr}$ of collection (semen ejaculates were individually evaluated microscopically and the ejaculates, which showed active progressive motility percentages $(\geq 70 \%)$ were pooled and extended to Tris-buffer extender. 
Table1. Composition and determined analysis (on a dry matter basis) of the experimental commercial diet used

\begin{tabular}{|c|c|}
\hline Ingredients & $\%$ \\
\hline Yellow corn & 6.22 \\
\hline Soybean meal, $44 \%$ & 22.33 \\
\hline Wheat bran & 23.33 \\
\hline Barley & 15.00 \\
\hline Alfalfa hay & 30.12 \\
\hline Ground limestone & 1.00 \\
\hline Di-calcium phosphate & 1.20 \\
\hline Common salt & 0.50 \\
\hline Vit. + Min. premix ${ }^{*}$ & 0.30 \\
\hline Total $/ \mathrm{kg}$ & 100 \\
\hline \multicolumn{2}{|l|}{ Calculated analysis $^{* * *}$} \\
\hline Crude protein, $\%$ & 18.8 \\
\hline Crude fiber, $\%$ & 13.0 \\
\hline Ether extract, \% & 3.0 \\
\hline Digestible energy ( $\mathrm{kcal} / \mathrm{kg}$ diet) & 2680 \\
\hline n-6 PUFAs\% & 0.3 \\
\hline n-3 PUFAs $\%$ & 1.03 \\
\hline$n-6 / n-3$ ratio & $0.3: 1$ \\
\hline \multicolumn{2}{|l|}{ Determined analysis $(\mathrm{g} / \mathrm{kg})$} \\
\hline Dry matter & 902.4 \\
\hline Organic matter & 912.1 \\
\hline Crude protein & 172.4 \\
\hline Crude fiber & 138.5 \\
\hline Ether extract & 26.2 \\
\hline Nitrogen-free extract & 575.0 \\
\hline Ash & 87.9 \\
\hline \multicolumn{2}{|l|}{ Cell wall constituents $(\mathrm{g} / \mathrm{kg})$} \\
\hline Neutral detergent fiber (NDF) & 331.1 \\
\hline Acid detergent fiber (ADF) & 160.9 \\
\hline Hemicellulose & 170.2 \\
\hline
\end{tabular}

Each $3 \mathrm{~kg}$ of premix contains: Vit. A: 12,000,000 IU; Vit. D3: 3,000,000 IU; Vit. E:10.0 mg; Vit. K3: $3.0 \mathrm{mg}$; Vit. B1: $200 \mathrm{mg}$ : Vit. B2: $5.0 \mathrm{mg}$ Vit. B6: $3.0 \mathrm{mg}$ : Vit. B12: 15.0 $\mathrm{mg}$; Biotin: $50.0 \mathrm{mg}$; Folic acid: $1.0 \mathrm{mg}$; Nicotinic acid: $35.0 \mathrm{mg}$ : Pantothenic acid: 10.0 mg; Mn: 80 g; Cu: 8.8 g; Zn: 70 g; Fe: 35 g; I: 1 g; Co: 0.15 g and Se: $0.3 \mathrm{~g}$. 
Table 2. Polyunsaturated fatty acid analysis of sesame, linseed and sunflower oils

\begin{tabular}{|c|c|c|c|c|c|c|}
\hline \multirow{2}{*}{ Type of oil } & \multicolumn{6}{|c|}{ Mean Fatty acids \% } \\
\cline { 2 - 7 } & $\begin{array}{c}\text { Palmatic } \\
16: 0\end{array}$ & $\begin{array}{c}\text { Stearic } \\
18: 0\end{array}$ & $\begin{array}{c}\text { Olic } \\
18: 1\end{array}$ & $\begin{array}{c}\text { Linoleic } \\
(\mathrm{n}-6) 18: 2\end{array}$ & $\begin{array}{c}\text { Linolenic } \\
(\mathrm{n}-3) 18: 3\end{array}$ & $\begin{array}{c}\mathrm{n}-6 / \mathrm{n} 3 \\
\text { Ratio }\end{array}$ \\
\hline $\begin{array}{c}\text { Sesame oil } \\
\text { (Ses) }\end{array}$ & 8.47 & 5.53 & 41.63 & 42.77 & 0.42 & $\mathbf{1 0 1 : 1}$ \\
\hline $\begin{array}{c}\text { Linseed oil } \\
\text { (Lin) }\end{array}$ & 5.51 & 3.8 & 13.5 & 14.8 & 62.1 & $\mathbf{0 . 2 4 : 1}$ \\
\hline $\begin{array}{c}\text { Sunflower } \\
\text { (Sun) }\end{array}$ & 6.65 & 4.97 & 52.83 & 33.15 & 0.51 & $\mathbf{6 5 : 1}$ \\
\hline
\end{tabular}

Polyunsaturated fatty acid composition of Sesame, linseed and sunflower oils are based on references by Hassan (2012) ${ }^{1}$, El-Prollosy, (2012) ${ }^{2}$ and Ismaill and Arafat (2014), respectively.

*Mix oil, the ratio of $n-6 / n 3$ ratio calculated according to previous analysis recorded 1.4:1

The final concentration rate was $80-100 \times{ }^{10}$ motile sperm $/ \mathrm{ml}$. The insemination was immediately followed by the administration of $0.8 \mu \mathrm{g}$ of buserelin IM (0.2 ml Receptal; Hoechst, Frankfurt, Germany) to induce ovulation (Lopez and Alvariño, 2000).

\section{Blood biochemical constituents :}

Blood samples $(3 \mathrm{ml})$ were withdrawn at morning from marginal ear veins for each treatment group before access feed and water.

Blood samples were centrifuged at 3000 r.p.m for $15 \mathrm{~min}$ to obtain clear serum samples and stored at $-20{ }^{\circ} \mathrm{C}$ until analysis the following hormones.

\section{Determination hormones:}

Serum samples were used for determining the concentrations of E217- $\beta$ (the Estradiol ELISA Test Kit has a sensitivity of $6.5 \mathrm{pg} / \mathrm{ml}$ ) and P4 (the Progesterone ELISA Test Kit has a sensitivity of $0.105 \mathrm{ng} / \mathrm{ml}$ ) by Immunoassay Technique Elisa Kits (Fortress Diagnostics Ltd, Antrim, $\mathrm{UK})$, and PG concentrations of prostaglandin $\left(\mathrm{PGF}_{2 \alpha}\right)$ were measured using a PG ELISA kit (the Sensitivity: 50\% B/B0:52 pg/ml) (Cayman Chemicals, Ann Arbor, MI, USA).

\section{Reproductive performance:}

Sexual receptivity of does was tested in the presence of a vasectomies buck as described by the International Rabbit Reproduction Group (2005). Fertility rate (number of parturitions/number of inseminations $\times 100$ ), litter size (total number of born) and bunny body weight at birth were recorded. 


\section{Statistical analysis:}

All data were subjected to analysis of variance as described in SAS (program) (SAS, 2002).

The significant means differences among groups were separated by Duncan's multiple rang test (Duncan, 1955).

\section{RESULTS AND DISCUSSION}

\section{Reproductive hormones concentration:}

Table 3 shows the effect of different PUFAs oils administration as sources of n-3 and n-6 for aging does on E217 $\beta$, P4 and PGF $2 \alpha$ hormonal concentrations. The obtained data revealed that $\mathrm{E} 217 \beta$ and $\mathrm{PGF}_{2 \alpha}$ hormone concentrations for all groups were higher $(\mathrm{P} \leq 0.01)$ compared to those for control group. However the rabbits of Ses and Sun oils groups recorded a highest $\mathrm{E} 217 \beta, \mathrm{PGF}_{2 \alpha}$ concentration and low progesterone value than those for the Lin and Mix oils or control groups. Results show that there were no statistical differences between Lin and Mix oils groups with respect to $\mathrm{E} 217 \beta, \mathrm{P} 4$ and $\mathrm{PGF}_{2 \alpha}$ hormones. On the other hand, control group exhibited significantly the lowest concentration of E217 $\beta$ and $\mathrm{PGF}_{2 \alpha}$ besides highest level of progesterone hormone.

Essential reproductive hormones are E2, P4 and $\mathrm{PGF}_{2 \alpha}$. Estradaiol17 $\beta$ is involved with the preparation of the reproductive genital tracts for ova fertilization and the initiation of pulsative surge of LH (Ball and Peters, 2004). Progesterone is one of the majority prominent fertility hormones safe for carrying out pregnancy to period, whereas $\mathrm{PGF}_{2 \alpha}$ acts against the service of $\mathrm{P} 4$ on the $\mathrm{CL}$ after failed fertilization (Funston, 2004). Cows fed sources of omega-6 PUFAs are known to produce more cholesterol. Omega-3 PUFAs enables P4 to be synthesized by negatively affecting $\mathrm{PGF}_{2 \alpha}$ synthesis (Mattos et al., 2004). The cholesterol can be used in the presence of steroidogenic acute regulatory hormone to synthesize P4 (Piccinato et al., 2010).

Different type of cells, membranes and phospholipids have various compositions of PUFAs and these fatty acids composition may be affected by metabolism, state of cell activation, hormone, and genetic factors (Calder, 2015). The physical features of cell membrane that include fluidity and permeability are influenced by unsaturated fatty acids composition of cell membrane, furthermore, the unsaturated fatty acids as precursors are 
Table 3. Effect of unsaturated fatty acids on serum estradaiol17- $\beta$, progesterone and prostaglandin $\mathrm{F}_{2 \alpha}$ for aged V-line doe rabbits

\begin{tabular}{|l|c|c|c|c|c|c|}
\hline Parameters & Control & Ses & Lin & Sun & Mix & Sig test \\
\hline \multicolumn{7}{|c|}{ 3 ml oil/doe/day } \\
\hline E217- & $22.23^{\mathrm{c}}$ & $47.65^{\mathrm{a}}$ & $33.98^{\mathrm{b}}$ & $45.21^{\mathrm{a}}$ & $35.22^{\mathrm{b}}$ & $* *$ \\
B,(pg/mL) & \pm 0.84 & \pm 0.91 & \pm 0.41 & \pm 0.91 & \pm 0.54 & \\
\hline P4 & $4.39^{\mathrm{a}}$ & $1.88^{\mathrm{c}}$ & $2.45^{\mathrm{b}}$ & $1.89^{\mathrm{c}}$ & $2.37^{\mathrm{b}}$ & $*$ \\
$(\mathbf{n g} / \mathbf{m l})$ & \pm 0.04 & \pm 0.07 & \pm 0.08 & \pm 0.06 & \pm 0.12 & \\
\hline PGF2 $\alpha$ & $450.97^{\mathrm{c}}$ & $612.34^{\mathrm{a}}$ & $580.25^{\mathrm{b}}$ & $605.12^{\mathrm{a}}$ & $598.22^{\mathrm{b}}$ & $* *$ \\
$(\mathbf{n g} / \mathbf{m l})$ & \pm 12.23 & \pm 17.4 & \pm 13.5 & \pm 13.6 & \pm 12.23 & \\
\hline
\end{tabular}

a,b,c Means within the same row for each effect with different superscripts are significantly different $(\mathrm{P} \leq 0.05)$.

Sesame oil $=$ Ses, Linseed oil $=$ Lin, Sunflower oil $=$ Sun, Estradiol $17-\beta,=E 217-\beta$ pg $/ \mathrm{mL}$,

Progesterone $=\mathrm{P} 4 \mathrm{ng} / \mathrm{ml}$, Prostaglandin $=, \mathrm{PGF}_{2 \alpha} \mathrm{ng} / \mathrm{ml}$

* $\quad \mathrm{P} \leq 0.05 * * \mathrm{P} \leq 0.01$

related to prostaglandins (PGs) synthesis and steroidogenesis (Stocco et al., 2005).

Current results indicated that increasing concentration of $\mathrm{PGF}_{2 \alpha}$ by treatment with different oils are in agreement with those reported by Petit et al., (2004) who revealed that the linoliec acids as Ses and Sun oils (C18:2,n-6) are converted into arachidonic acid (C20:4, n-6), which is the precursor of the dienoic (2-series) PGs, such as $\mathrm{PGF}_{2 \alpha}$, while, omega-3 in Lin oil ( $\alpha$-linolenic acid; C18:3n-3) is converted into eicosapentaenoic acid (C20:5n-3), which is the precursor of the trienoic (3- series) PGs, such as $\mathrm{PGF}_{3 \alpha}$.

Moreover, Mattos et al., (2004) showed that feeding a diet rich in linoleic acid could contribute to increasing secretion of PGF $2 \alpha$, compared with feeding a diet rich in linolenic acid. Harmony with the context, Lands (1992) reported that the proportion of different PUFAs in the diet alters cell membrane phospholipid composition and this becomes quantitatively significant because the precursors of each group of PGs compete for the same enzyme systems for metabolism. This in turn will have considerable effects on the types of PG synthesized and hence, physiological responses (Abayasekara and Wathes, 1999). Also, Cheng et al., (2004) recommended that the supplementation of linoleic acids to endometrial cells in vitro isolated from late pregnant ewes caused a significant decrease in production of 2-series PGs. 
Diminishing P4 concentration due to using unsaturated fatty acids in this excremental is in harmony with results reported by Rebollar et al., (1992) who stated that the $\mathrm{PGF}_{2 \alpha}$ posses luteolytic properties in rabbits and induce a fall in $\mathrm{P} 4$ concentration. Same results obtained by Robinson et al., (2002) who demonstrated that feeding cows with a Linseed rich diet (linoleic acid, C: 18:3, n-3) leads to significant reduce of plasma P4 concentrations. Likewise, Acosta et al., (2002) and Beatrice and Ulrich, (2012) reported that administration of $\mathrm{PGF}_{2 \alpha}$ significantly decreased the volume of the CL and the blood P4 concentration of cyclic cows. On the other hand, Tran et al., (2016) demonstrate that the DHA increase GnRH enhancer-derived RNA levels. Overall, these provide evidence that GnRH neurons directly sense FFAs. This will advance our understanding of the mechanisms underlying FFA sensing in the brain and provides insight into the links between nutrition and reproductive function. Furthermore, Thatcher et al., (2006) revealed that injected of $\mathrm{PGF}_{2 \alpha}(0.5 \mathrm{mg}$ dinoprost, a synthetic analogue of $\mathrm{PGF}_{2 \alpha}$ ) impacts on increasing blood $\mathrm{PG}$ profile and decreasing blood $\mathrm{P} 4$ and this effect provided the opportunity to increased secretion of gonadotropin hormones from the pituitary and secretion estrogen from the ovary through inhibiting the effect of $\mathrm{P} 4$ on gonadotropin release. Whereas, increased biological effect of $\mathrm{PGF}_{2 \alpha}$ from Sun led to a decrease in blood P4 and an increase in blood 17- $\beta$ E2 level, which is necessary for the growth and maturation of oocytes (Thatcher et al., 2006). Besides, E2 can increase the sensitivity of the CL to $\mathrm{PGF}_{2 \alpha}$, thus causing a more complete regression of the CL (Howard et al., 1990). On the other hand, $\mathrm{PGF}_{2 \alpha}$ reduced the production of $\mathrm{P} 4$ because PUFAs converted to $\mathrm{PGF}_{2 \alpha}$ that caused an increase PGF concentration in the plasma with a reduction of the P4 synthesis (Thatcher et al., 2006). According to Smits (2010), the follicular phase begins after luteolysis and ends at ovulation. Gonadotropins $(\mathrm{GnRH})$ released from hypothalamus, FSH and $\mathrm{LH}$, released from the anterior pituitary, stimulate follicles to produce E2 and the follicular phase is dominated by E2, which produced by developing follicles (Adams, 1999).

Present data on Ses and Sun oils revealed that the $\mathrm{PGF}_{2 \alpha}$, which produced in vivo from $n-6$ (PG precursor) more effective on reproductive functions of rabbit does than that of the synthetic $\mathrm{PGF}_{2 \alpha}$. Also, current results revealed that Ses and Sun oils as a precursor of $\mathrm{PGF}_{2 \alpha}$ had a biological activity more than the Lin and Mix oils as a precursor of $\mathrm{PGF}_{3 \alpha}$. This finding was consistent with the finding of Lauderdale (2002) who found that in domestic animals, the most important and practical utility of 
PG appears to be $\mathrm{PGF}_{2 \alpha}$ and the actions of $\mathrm{PGF}_{2 \alpha}$ are mediated by the PGF receptor (Sugimoto et al., 1994). Finally, Elkomy and Elspeiy (2015) reported that treated aged rabbit does by oral administration with Sun oil improved reproductive hormone synthesis and secretion, this demonstrated that treated aged does with PUFAs is a good tool for improving the reproductive traits.

\section{Reproductive performance:}

Date of Table 4 showed that all groups of rabbit does received different oil sources either separated or combined represented significant $(\mathrm{P} \leq 0.01)$ increase of sexual receptivity, fertility rate, litter size and body weight at birth in treated groups compared with control. However, rabbits of Ses and Sun oils groups significantly $(\mathrm{P} \leq 0.01)$ recorded highest sexual receptivity and fertility percentages besides low litter size and body weight at birth than those for Lin and Mix oils groups. Also, results showed that there were no statistical differences between Ses and Sun oils groups with respect to previous mentioned parameters. Interestingly, doe rabbits of Lin and Mix oils groups represented highest $(\mathrm{P} \leq 0.01)$ records than other groups with respect to litter size and body weight at birth, while control group recorded low values for all studied parameters.

Table 4. Effect of unsaturated fatty acids on sexual receptivity, fertility rate, litter size and bunny weight at birth of aged V-line multiparous does

\begin{tabular}{|l|c|c|c|c|c|c|}
\hline \multicolumn{1}{|c|}{ Parameters } & Control & Ses & Lin & Sun & Mix & Sig test \\
\hline Sexual receptivity, & $58.43^{\mathrm{c}}$ & $82.67^{\mathrm{a}}$ & $75.34^{\mathrm{b}}$ & $84.87^{\mathrm{a}}$ & $77.35^{\mathrm{b}}$ & $* *$ \\
\% & \pm 2.89 & \pm 1.78 & $\pm 1.42^{\mathrm{y}}$ & \pm 1.84 & \pm 1.44 & \\
\hline Fertility rate, & $51.19^{\mathrm{c}}$ & $80.45^{\mathrm{a}}$ & $71.23^{\mathrm{b}}$ & $82.22^{\mathrm{a}}$ & $73.42^{\mathrm{b}}$ & $* *$ \\
\% & \pm 1.56 & \pm 1.54 & \pm 124 & \pm 1.31 & \pm 1089 & \\
\hline L.S.at birth & $4.98^{\mathrm{c}}$ & $8.11^{\mathrm{b}}$ & $8.54^{\mathrm{a}}$ & $8.08^{\mathrm{b}}$ & $7.75^{\mathrm{b}}$ & $* *$ \\
(n) & \pm 0.73 & \pm 1.45 & \pm 0.61 & \pm 0.56 & \pm 0.67 & \\
\hline B.W.at birth & $41.21^{\mathrm{c}}$ & $44.11^{\mathrm{b}}$ & $47.25^{\mathrm{a}}$ & $43.65^{\mathrm{b}}$ & $45.82^{\mathrm{a}}$ & $* *$ \\
(g) & \pm 0.61 & \pm 0.59 & \pm 0.34 & \pm 0.78 & \pm 0.62 & \\
\hline
\end{tabular}

a,b,c Means within the same row for each effect with different superscripts are significantly different $(\mathrm{P} \leq 0.05 \mathrm{~s})$.

Sesame oil $=$ Ses, Linseed oil $=$ Lin, Sunflower oil $=$ Sun Litter size at birth $(\mathrm{n})=$ L.S.at birth $(\mathrm{n})$, Bunny weight at birth $(\mathrm{g})=\mathrm{B}$.W. at birth $(\mathrm{g})$

$* * \mathrm{P} \leq 0.01$ 
Current results for that increasing concentration of $\mathrm{PGF}_{2 \alpha}$ by treatment with different oils and sexual receptivity improvement are in agreement with those reported by Dragan et al., (1996) who mentioned that sexual receptivity of rabbit does by rise level of $\mathrm{PGF}_{2 \alpha}$ analogues is improved than the control. Also, Hassanein (2000) found that the increased percentage of mating acceptance was $100 \%$ when does were treated with lutalyase ( $\mathrm{PGF}_{2 \alpha}$ analogues) $48 \mathrm{~h}$ before natural mating.

The results of this research proved that amendment in dietary PUFAs significantly increases fertility rate due to raise of $\mathrm{PGF}_{2 \alpha}$. This result is keeping with those previously reported by Facchin et al., (1992) who stated that injected $\mathrm{PGF}_{2 \alpha}$ before insemination for rise PG level to induce oestrus synchronization of multiparous doe rabbits. Moreover, Alvarino et al., (1995) observed that $\mathrm{PGF}_{2 \alpha}$ improved the fertility rate in nulliparous and multiparous inseminated does. Similarly, results of Gogol (2009) showed that simultaneous treatment with $\mathrm{PGF}_{2 \alpha}$ to induce oestrus synchronization can increase reproductive performance in postpartum rabbit does, whereas, fertility rate and litter size were significantly increased in multiparous does treated with unsaturated fatty acids. On the other hand, Adamiak et al., (2005) showed that PUFAs content in follicular fluid is highly correlated to that of the diet and it is generally accepted that alterations in dietary fatty acid intake cause a similar shift in the fatty acid profile of the follicular fluid. In addition, Zachut et al., (2008) mentioned that supplemented diet with lipid increases the size of the pre-ovulatory follicle and its production of E2. Otherwise, the lipids stored within the oocyte and early embryo represents an important source of energy for the early embryo (Mc Keegan and Sturmey, 2012). Moreover, Kowalska (2008) found that the female rabbits fed a complete diet fish oil (n-3) supplemented had a quantitavely and qualititavely better milk fat content, higher fertility prolificacy values, and higher body weight of young rabbits at birth. The observed effects in this study regarding the increase of litter size, fertility and higher body weight at birth support the conclusion of Nemeth et al., (2017) who recorded that PUFAs supplementation may contribute to an adjustment of energy accumulations to the total litter mass, which may both favor a mother's body condition at parturition and perhaps increase the offspring survival at birth.

In conclusion, supplementing the aged doe rabbits with sesame, linseed, sunflower and their mixture could be a useful tool for improving reproductive hormones, sexual receptivity, fertility rate, litter size and weight at birth. 


\section{Acknowledgment:}

Our sincere appreciation and deep gratitude are extended to Dr. Mohamed Elspeiy, Chief Researcher of Rabbit Physiology in APRI for his counsel, great and kind assistance and providing facilities during this study.

\section{REFERENCES}

Abayasekara, D.R.E. and Wathes, DC., (1999). Effects of altering dietary fatty acid composition on prostaglandin synthesis and fertility. Prostaglandins Leukot Essent Fatty Acids; 61:275-287.

Acosta, T.J.; Yoshizawa, N.; Ohtani, M. and Miyamoto, A., (2002). Local changes in blood flow within the early and midcycle corpus luteum after prostaglandin F2 $\alpha$ injection in the cow. Biol. Reprod., 66: 651658.

Adamiak, S.J.; Mackie, K.; Watt, R.G.; Webb, R. and Sinclair, K.D., (2005). Impact of nutrition on oocyte quality: Cumulative effects of body composition and diet leading to hyperinsu-linemia in cattle. Biol. Reprod., 73: 918-926.

Adams, C.E., (1970). Aging and reproduction in the female mammal with particular reference to the rabbit. J. Reprod. Fert. Suppl. 12, 1.

Adams, G.P., (1999). Comparative patterns of follicle development and selection in ruminants. J. Reprod. Fertil. 54: 17-32.

Ahmed, N.A.; Ebbiary, E.A. Lenton, I.D. and Cooke, A.M. (1994). Hypothalamic-pituitary ageing: progressive increase in FSH and LH concentrations throughout the reproductive life in regularly menstruating women. Clin Endocrinol (Oxf), 41, pp. 199-206.

Alvarino, J.M.R.; Rebollar, P.G.; Arco, J.A. and Torres, R., (1995). Estimulation ovarica en la coneja mediante prostaglandina F2 $\alpha$ y PMSG. ITEA-Inf. Tec. Econ. Ag. , 16:461-463.

Ball, P.J.H. and Peters, A.R., (2004). Reproduction In Cattle. $3^{\text {rd }}$ ed. Oxford: Blackwell Publishing Ltd.

Beatrice, W. and Ulrich, B., (2012). Effect of a prostaglandin F2 $\alpha$ analogue on the cyclic corpus luteum during its refractory period in cows. $B M C$ Vet. Res., 8: 220. 
Calder, P.C., (2015). Functional roles of fatty acids and their effects on human health. J. Pen-Parenter Enter, Vol.39 (1 suppl); pp.18S-32S.

Carnevale, E.M. and Ginther, O.J., (1992). Relationships of age to uterine function and reproductive efficiency in mares. Theriogenology; 37:1101-1115. 41 .

Cheng, Z.; Elmes, M.; Kirkup, S.E.; Abayasekara, D.R.E. and Wathes, D.C., (2004). Alteration of prostaglandin production and agonist responsiveness by $n-6$ polyunsaturated fatty acids in endometrial cells from late gestational ewes. J. Endocrinol. ; 182: 249-256

Deng, M., (2012). Mechanisms of reproductive aging in the females. Sci China Life Sci., 55: pp. 653-658.

Dragan, N.; Muscalu, G.R.; Cocu, F.; Cimpeanu, I.; Bunaciu, M.; Dumitru, P.; Stefanescu, D., and Pop, T., (1996). Effect of prostaglandin analogues on sexual receptivity, fecundity and pregnancy of does. Proc. $6^{\text {th }}$ World Rabbit Congr., Toulouse, France, 65-67.

Duncan, D.B., (1955). Multiple range and multiple F tests. Biometrics, 11: 142.

Elkomy, A.E. and El-Speiy, M.E., (2015). Polyunsaturated Fatty Acids Combined with Equine Chorionic Gonadotropin to Enhance Reproductive Performance in Aged Rabbit Does. Italian Journal of Animal Science; Volume 14: 3535.

El-Prollosy, A.A., (2012). Effect of photoperiod and the ratio between omega- 3 and omega- 6 fatty acids on productive and reproductive performance and immune response of local laying hens. Ph.D. Thesis, Fac. of Agric. Damanhour University.

Facchin, E.; Castellini, C.; Rasetti, G. and Ballabio, R., (1992). L'impiego di prostaglandina sin- tetica (alfaprostol) e di PMSG nella sin- cronizzazione degli estri e dei parti. Riv. Zoot. Vet., 20: 11-14.

Field, T.G. and Taylor, R.E., (2008). Scientific farm animal production, an introduction to animal science. $9^{\text {th }}$ ed. New Jersey Columbus: Pearson, Prentice Hall.

Fouladi-Nashta, A.A.; Wonnacott, K.E.; Gutierrez, C.G.; Gong J.G.; Sinclair, K.D.; Garnsworthy, P.C. and Webb, R., (2009). Oocyte quality in lactating dairy cows fed on high levels of n-3 and n-6 fatty acids. Reproduction; 138: 771-781. 
Funston, R.N., (2004). Fat supplementation and reproduction in beef females. J. Animal Sci.; 82(13):154-161.

Gogol, P., (2009). Effect of prostaglandin F2 $\alpha$ on reproductive performance in rabbit does. Ann. Anim. Sci., 9: 395-400.

Hassan, Manal A., (2012). Studies on Egyptian Sesame Seeds (Sesamumindicum L.) and Its Products 1- Physicochemical Analysis and Phenolic Acids of Roasted Egyptian Sesame seeds (Sesamumindicum L.) World Journal of Dairy \& Food Sciences, 7:195-201.

Hassanein, Y.R.A., (2000). Effect of hormonal regimen on productive performance and biochemical parameters in female rabbits. Degree Diss., Alexandria University, Egypt.

Henderson, S.A. and Edwards, R.G., (1968). Chiasma frequency and maternal age in mammals. Nature, Lond. 218, 22.

Ingram, D.L.; Mandl, A.M. and Zuckerman, S., (1958). The influence of age on litter size. J. Endocr., 17, 280.

International Rabbit Reproduction Group. (2005). Guidelines for the handling of rabbit bucks. World Rabbit Sci., 13: 71 - 91.

Ismail Awatif, I. and Arafat, S.M., (2014). Quality characteristics of high-oleic sunflower oil extracted from some hybrids cultivated under egyptian conditions. Journal of Food Technology Research, Vol. 1, P: 73-83.

Kowalska, D., (2008). Effect of essential unsaturated fatty acids in fish oil on litters and composition of milk of rabbit does. Proc. $9^{\text {th }}$ World Rabbit Congr., Verona, Italy, pp 705-710

Lands, W.E.M., (1992). Biochemistry and physiology of n-3 fatty acids. FASEB; 6:2530-2536.

Larson, L.; Arson, L.L.; Spilman, C.H.; Dunn, H.O. and Foote, R.H., (1973). Reproductive efficiency in aged female rabbits given supplemental progesterone and oestradiol .J, Repro. Fert; 33: 31-38.

Lauderdale, J.W., (2002). Use of prostaglandin F2 $\alpha\left(\mathrm{PGF}_{2 \alpha}\right)$ in cattle breeding. In: M.J. Eields, R.S. Sand and J.V. Yelich (eds.) Factors affecting calf crop. Biotechnology Of Reproduction. CRC Press, London, UK, pp 23-33.

Lopez, J. and Alvariño, J.M.R., (2000). Effects of added caffeine on results following artificial insemination with fresh and refrigerated rabbit semen. Anim. Rep. Sci., Vol.58, Issues 1-2: pages 147-154. 
Mattos, R.; Staples, C.R.; Arteche, A.; Wiltbank, M.C.; Diaz, F.J. and Jenkins, T.C., (2004). The effects of feeding fish oil on uterine secretion of $\mathrm{PGF}_{2 \alpha}$, milk composition, and metabolic status of periparturient Holstein cows. J. Dairy Sci.; 87(4): 921-932.

Maurer, R.R. and Foote, R.H., (1971). Maternal ageing and embryonic mortality in the rabbit. I. Repeated superovulation, embryo culture and transfer. J. Reprod. Fert., 25, 329.

Maurer, R.R. and Foote, R.H., (1972). Maternal ageing and embryonic mortality in the rabbit. II. Hormonal changes in young and ageing females. J. Reprod. Fert., 31: 15.

Mc Keegan, P.J. and Sturmey, R.G., (2012). The role of fatty acids in oocyte and early embryo development. Reprod. Fert. Develop. 24:59- 67.

Meldrum, D.R.; Casper, R.F.; Diez-Juan A.; Simon, C.; Domar, A.D. and Frydman, R., (2016). Aging and the environment affect gamete and embryo potential: can we intervene Fertil Steril.; 105:548-559.

Nemeth, M.; Millesi, E.; Siutz, C.; Wagner, K.H.; Quint, R.; Wallner, (2017). Reproductive performance and gestational effort in relation to dietary fatty acids in guinea pigs. J Anim Sci Biotechnol. 18:28.

Petit, H.V.; Ermiquet, C. and Lebel, D., (2004). Effect of feeding whole, unprocessed sunflower seeds and flaxseed on milk production, milk composition, and prostaglandin secretion in dairy cows. J. Dairy Sci., 87:1-10.

Piccinato, C.; Sartori, R.; Sangsritavong, S.; Souza, A.; Grummer, R. and Luchini, D., (2010). In vitro and in vivo analysis of fatty acid effects on metabolism of $17 \beta$-estradiol and progesterone in dairy cows. J. Dairy Sci.; 93(5):1934-1943.

Rebollar, P.G.; Ubilla, E.; Rodriguez, J.M.; Illera, J.C. and Silvan, G., (1992). Induction of luteolysis by administration of a synthetic prostaglandin F2 $\alpha$ analogue in pseudopregnant rabbits. J. Appl. Rabbit Res., 15: 456-461.

Robinson, R.S.; Pushpakumara, P.G.A.; Cheng, Z.; Peters, A.R.; Abayasekara, D.R. and Wathes, D.C., (2002). Effects of dietary polyunsaturated fatty acids on ovarian and uterine function in lactating dairy cows. Reproduction, 124: 119-131. 
Santos, J.; Bilby, T.; Thatcher, W.; Staples, C. and Silvestre, F., (2008). Long chain fatty acids of diet as factors influencing reproduction in cattle. Reprod. Domestic Anim.; 43: 23-30.

SAS, Institute, (2002). SAS/ STAT User's guide statistics. SAS Institute INC., Cary, NC, USA.

Scott, T.A.; Shaver, R.D.; Zepeda, L.; Yandell, B. and Smith, T.R., (1995). Effects of rumen-inert fat on lactation, reproduction and health of high producing Holstein herds. J. Dairy Sci.; 78 (11): 2435-2451.

Simmen, R.C.; Heard, M.E.; Simmen, A.M.; Montales, M.T.; Marji, M.; Scanlon, S. and Pabona, J.M., (2015). The Kruppel-like factors in female reproductive system pathologies. J. Mol. Endocrinol.; 54:R89-R101.

Smits, R., (2010). Field evaluation of the benefits of fish oil dietary supplementation to mul- tiparous sows fed during lactation and early pregnancy on fertility. Available from: 109_Project_Final_Research_Report.

Stocco, D.M.; Wang, X.; J.O.Y. and Manna, P.R., (2005). Multiple signaling pathways regulating steroidogenesis and steroidogenic acute regulatory protein expression more complicated than we thought, Mol Endocrinol, Vol.19; pp.2647-2659.

Sugimoto, Y.; Hasumoto, K.; Namba, T.; Irie, A.; Katsuyama, M.; Negishi, M.; Kakizuka, A.; Narumiya, S. and Ichikawa, A., (1994). Cloning and expression of DNA for mouse prostaglandin $\mathrm{F}$ receptor. J. Biol. Chem. Jan. , 14; 269 (2):1356-60.

Talbert, G.B., (1968). Effect of maternal age on reproductive capacity. Am. J. Obstet. Gynec. , 102: 451.

Thatcher, W.W.; Bilby, T.R.; Bartolome, J.A.; Silvestre, F.; Staples, C.R. and Santos, J.E., (2006). Strategies for improving fertility in the modern dairy cow. Theriogenology, 65: 30-44.

Thorneycroft, I.H. and Soderwall, A.L., (1969). The nature of the litter size loss in senescent hamsters. Anal. Ree., 165: 343.

Tran, D.Q.; Ramos, E.H. And Belsham, D.D., (2016). Induction of GnRH mRNA expression by the $\omega-3$ polyunsaturated fatty acid docosahexaenoic acid and the saturated fatty acid palmitate in a GnRH-synthesizing neuronal cell model, mHypoA-GnRH/GFP. Mol Cell Endocrinol. May 5; 426:125-35 
Vrablik, T.L. and Watts, J.L., (2013). Polyunsaturated fatty acid derived signaling in reproduction and development: insights from Caenorhabditiselegans and Drosophila melanogaster. Mol. Reprod. Dev., 80:244-259.

Walker, D.M.; Kermath, B.A.; Woller, M.J. and Gore, A.C., (2013). Disruption of reproductive aging in female and male rats by gestational exposure to estrogenic endocrine disruptors. Endocrinology, 154, pp. 2129-2143

Wathes, D.C.; Abayasekara, D.R.E. and Aitken, R.J., (2007). Polyunsaturated fatty acids in male and female reproduction. Biol Reprod.; 77: 190-201.

Zachut, M.; Arieli, A.; Lehrer, H.; Argov, N. and Moallem, U. (2008). Dietary unsaturated fatty acids influence preovulatory follicle characteristics in dairy cows. Reproduction, 135: 683-692.

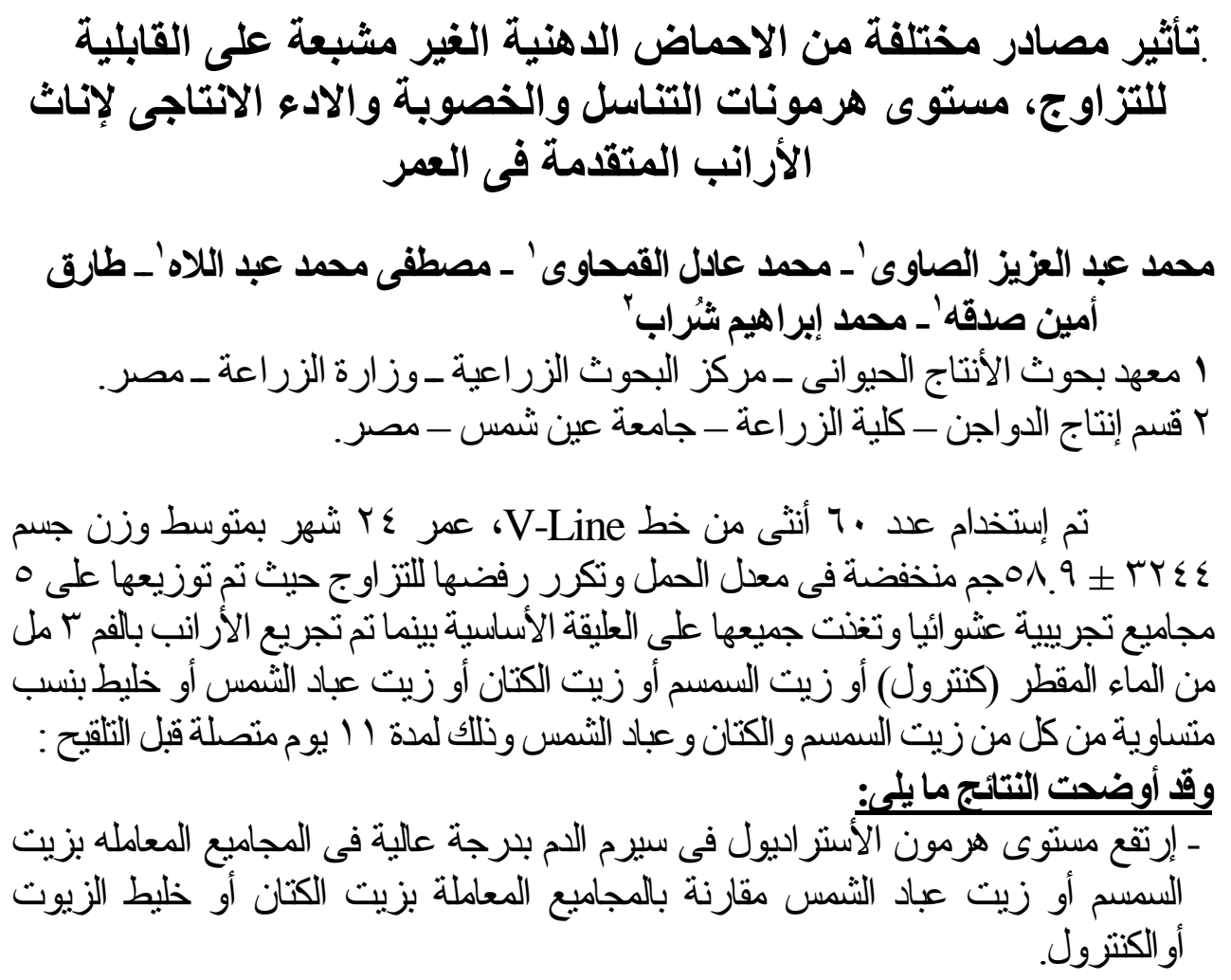


- إنخفض معنويا على مستوى (\% مستوى هرمون البروجنتيرون فى كل المجاميع المعاملة

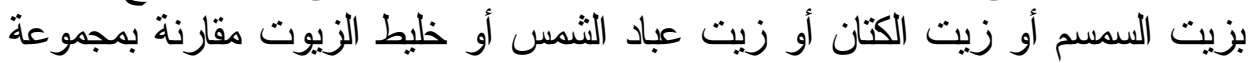

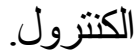

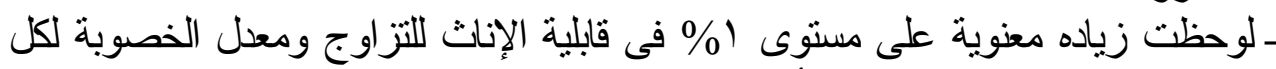
المجاميع المعامله بالزيوت الثلاثة أو خليطهم مقارنة بالكنترول.

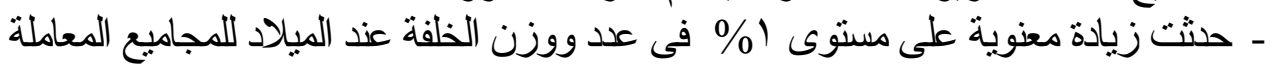
ب الزيوت الثلاثة أو خليطهم مقارنة بالكنترول.

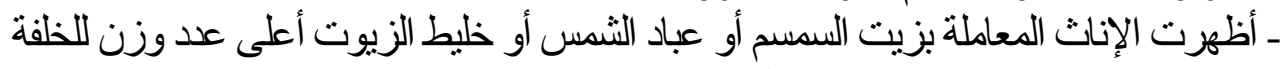

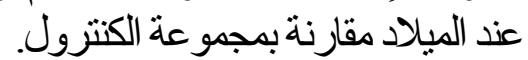

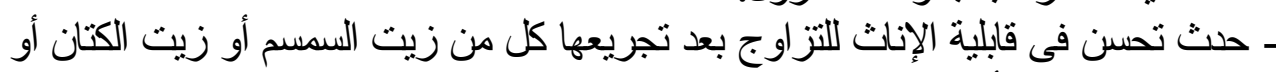

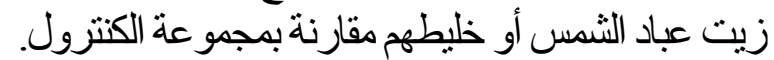

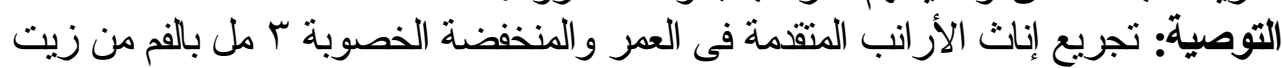

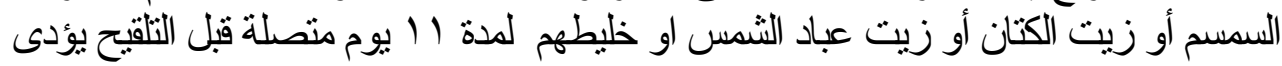
إلى تحسن مستوى هرمونات التناسل، القابلية للتزاوج ،علد الخلفة لإلفة ، وزنها عند الميلاد

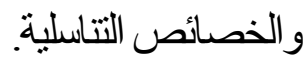

